\title{
Experimental studies to determine the physico-mechanical characteristics of soils improved with special hydraulic binders
}

\author{
Gabriela Andrieș ${ }^{1, *}$ and Loretta Batali $^{1}$ \\ ${ }^{1}$ Geotechnical Department, Technical University of Civil Engineering, Bucharest, Romania
}

\begin{abstract}
The complexity of the construction works and site conditions, combined with environmental factors, led to the necessity of using special mineral binders with physical and chemical properties superior to the usual binders. Taking into account the above arguments, the paper presents the results of experimental laboratory studies in order to determine the physical and mechanical characteristics of soil used for a road embankment, after improvement with a special lime-based hydraulic binder. Since improvement recipes vary from one soil to another, it is important to always determine the characteristics after treatment. Also, the method of mixing the binder and soil decisively determines subsequent performance. As part of a larger study aiming at assessing the various factors of influence on the treated soil characteristics, two comparative studies were carried out, each consisting in the recipe formulation using 3 different binder ratios, the difference being given by the parameters used for specimen compaction: normal or modified Proctor test. The study followed the influence of the mechanical compaction work on the mechanical behaviour of the specimens over time after different times of curing.
\end{abstract}

\section{Introduction}

Earth embankments are permanently submitted to external factors as rainfall, freezing/thaw or wetting/drying cycles which exert a strong influence on their behaviour. Temperature and humidity variation along the year leads to increase or decrease of bearing capacity of embankments, thus also of the strength and stability of road system.

In most cases site conditions or available materials are not appropriate for use in earthworks; therefore in order to use less adequate or even difficult soils, with low mechanical characteristics or swelling soils, an improvement is required.

Hydraulic binders are used for soil stabilisation and improvement as they allow using local soils for embankments and earthworks. The mixing of local soils with hydraulic binders allows not only to obtain a more cost-effective and rapid solution than the classical one, but also to reduce the carbon footprint and the environmental impact. Thus, even known from many years, the researches in this field are very actual and focused on special hydraulic binders and on the properties of improved soils.

The paper presents the results of experimental laboratory studies in order to determine the physical and mechanical characteristics of soil used for a road embankment, after improvement with a special lime- based hydraulic binder. Since improvement recipes vary from one soil to another, it is important to always determine the characteristics before and after treatment. Also, the method of mixing the binder and soil decisively determines subsequent performance. In this case the paper was focused only on the influence of the compaction mechanical work (normal or modified Proctor), but the results are part of a broader study aiming at assessing the various factors of influence on the treated soil characteristics.

The experimental study has been carried out on samples created in laboratory, the soil being a sandy clay $(\mathrm{saCl})$ which was mixed with three different percentages of special lime-based binder. The mixed samples have been then compacted with two different values of compaction energy corresponding to normal and modified Proctor tests and the mechanical characteristics determined (unconfined compression strength and compressibility).

On site have been carried out two experimental plots for which the compaction has been performed at $98 \%$ of the optimum normal or modified Proctor and Lukas plate tests have been performed after different periods of time after the mixing.

Paper presents the results for the physical and mechanical characteristics of the treated soils in order to show that curing time and compaction energy are fundamental for obtaining an effective stabilisation.

* Corresponding author: gabiandries@yahoo.com 


\section{Basic theoretic principles}

Lime-based hydraulic binders are generally used for stabilising soils with plasticity index higher than $10 \%$, while for lower values a treatment with cement-based binders is recommended [1]. It is well known that soil stabilisation with lime-based binders is taking place due to short term reactions as lime hydration for quick lime, cation exchange and flocculation and to long term reactions of puzzolanic type. The short term reactions are responsible for plasticity decrease and texture change, while the long term ones for the strength and durability increase [2].

Whilst the pozzolanic reaction process is widely accepted as a concept, the detail surrounding a lime - clay cementitious reaction is poorly understood, some researchers noting a general lack of agreement amongst researchers, relating to the timescale and location of the reactions. This was attributed to the wide variety of clay soil compositions and complexity of clay mineral structures [3].

After treatment of clayey soils with lime-based hydraulic binders the following improvements are obtained [2]:

- Modification of soil structure (flocculation or granulation) due to bonds created by $\mathrm{Ca}(\mathrm{OH})_{2}$ or $\mathrm{CaOH}^{+}$ between the clay platelets. This is translated into: an increase of plasticity limit (WP) and decrease of plasticity index $\left(\mathrm{I}_{\mathrm{P}}\right)$, modification of the compaction curve (Proctor), increase of the soil aptitude to compaction and increase of mechanical characteristics (bearing capacity, shear strength) and, also, of the durability (better behaviour to wetting/drying and freeze/thaw cycles)

- Soil desiccation: decrease of soil water content due to lime reaction and to mixing procedure

The current state of the art demonstrates that lime migration may instigate diffuse cementation throughout larger clods of clay soil. The rate that strength gain is achieved with cementation is influenced by several factors and a high degree of soil saturation is substantial significance. The optimal combination of binders and different soil type is not known. This acknowledges the absence of a "one size fits all" approach and the importance of selecting binder type, mellowing periods and moisture conditioning based upon suitability to achieve the required engineering performance [4].

\section{Materials and procedures}

The soil used for the experiments was obtained by mixing $45 \%$ of fat clay (plasticity index $\mathrm{I}_{\mathrm{P}}=51,4 \%$ - very high plasticity, free swell $\mathrm{U}_{\mathrm{L}}=100 \%$ ) with $55 \%$ of poorly graded sand $\left(\mathrm{C}_{\mathrm{u}}=3.5\right)$. It resulted a sandy clay $(\mathrm{saCl})$ with high plasticity $\left(\mathrm{I}_{\mathrm{p}}=25 \%\right)$ and medium free swell $\left(\mathrm{U}_{\mathrm{L}}\right.$ $=60 \%$ ), whose grain size curve is presented in figure 1 .

The hydraulic binder that has been used is composed of a mix of calcium lime and hydraulic components. It has hydraulic properties, which makes it useful for improving the physical and mechanical characteristics of cohesive soils (plasticity index, free swell, moisture content decreasing, bearing capacity increasing) for long-term stabilization.

The binder has been added in three percentages: $1,5 \%$, $2 \%$ and $2.5 \%$. These admixtures aimed at finding the optimum composition in terms of maximum mechanical characteristics, but also taking into account the cost effectiveness.

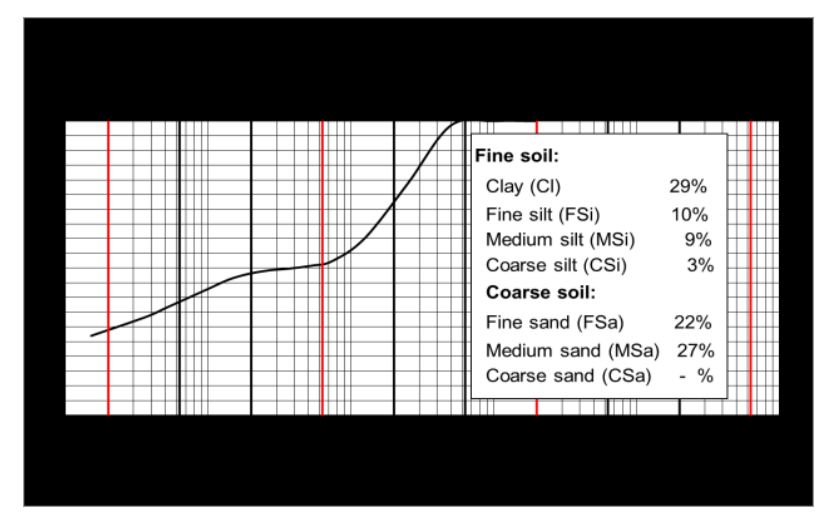

Fig. 1. Grain size distribution of the studied soil.

The tests performed on the stabilised soil have been conducted according to Romanian standards and the following characteristics have been determined:

- grain size distribution;

- water content;

- compaction characteristics (Proctor test in 2 versions: normal with a compaction energy of $0.6 \mathrm{MJ} / \mathrm{m}^{3}$ and modified with an energy of $\left.2.7 \mathrm{MJ} / \mathrm{m}^{3}\right)$;

- compression strength (unconfined compression strength);

- compressibility in oedometer;

- Lukas plate tests performed on site.

The obtained values have been compared with the allowable ones provided by Romanian standards STAS 12253-84 [5] and STAS 10473/1-87 [6] for strength and bearing capacity.

Different curing times have been considered: $3,7,14$, 28 days. The samples have been kept in humid environment during the curing time.

\section{Results}

Table 1 presents the results obtained for $1,5 \%, 2 \%$ and $2.5 \%$ in terms of grain size distribution and free swell, after different time of curing (3, 7, 14, 28 days).

Results in table 1 show that for binder addition of more than $2 \%$ a change of the soil internal structure is produced for 28 days of curing. A significant part of the colloidal clay is transferred to the sand fraction, thus the texture being modified. As a consequence, also the free swell is reduced. Changes in the clay fraction show a wide range of response to the addition of lime based binder although for most of the soils there is a gradual and continuous decrease in clay content with increasing lime content. Clearly the alteration of the clay fraction and the formation of particle aggregates is complex and shows differing behaviour over the full range of added binder [7]. 
For these admixtures were also determined the compaction characteristics which are depicted in figures 2 and 3 for the two considered Proctor tests (normal and modified). One can note that as the binder addition increases, the optimum water content also increases, while the maximum dry density decreases, therefore the curves obtained for treated soils are below and on the right side (the "wet" side) of the untreated soil curve. The increase in the optimum water content is due to the need of lime hydration -a part of the water is used for the hydration of quicklime. This is particularly interesting for clayey soils being wetter than the optimum water content, therefore by mixing with lime-based binders these soils can be further used for earthworks. Also, it can be seen that curves are flattened compared to the natural soil, these showing that the relative compaction state $\left(\rho_{\mathrm{d}} / \rho_{\mathrm{dmax}}\right)$ of treated soils is improved. Therefore, the aptitude of soils for compaction and their workability are improved. Similar findings are reported in the literature, as for example in [7] where the optimum moisture content of the samples increases and maximum dry density decreases as pozzolan and lime content increases. This is explained by [7] as follows: by increasing the amounts of additives, which are finer than silty sandy soil, the treated sample tend to be finer and having higher void ratio and thereby causes the increasing of optimum water content., which always lead to a decrease of the maximum dry density.

Table 1. Grain size distribution and free swell after treatment.

\begin{tabular}{|c|c|c|c|c|c|c|}
\hline \multirow[t]{2}{*}{$\begin{array}{l}\dot{0} \\
\dot{\mathrm{Z}}\end{array}$} & \multirow[t]{2}{*}{ 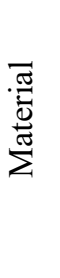 } & \multirow[t]{2}{*}{ Tcuring } & \multicolumn{3}{|c|}{$\begin{array}{c}\text { Grain size } \\
\text { distribution acc. to } \\
\text { SR EN ISO } 14688- \\
1: 2004 / A 1: 2014 \\
(\%)\end{array}$} & \multirow{2}{*}{$\begin{array}{c}\text { Free swell } \\
\text { acc. to } \\
\text { STAS } \\
1913 / 12- \\
88 \\
\%\end{array}$} \\
\hline & & & $\begin{array}{l}\text { Clay } \\
(\mathrm{Cl})\end{array}$ & $\begin{array}{l}\text { Silt } \\
\text { (Si) }\end{array}$ & $\begin{array}{l}\text { Sand } \\
(\mathrm{Sa})\end{array}$ & \\
\hline 1 & (1) & - & 29 & 22 & 49 & 60 \\
\hline 2 & \multirow{4}{*}{ (2) } & 3 & 28 & 22 & 50 & 60 \\
\hline 3 & & 7 & 27 & 22 & 51 & 60 \\
\hline 4 & & 14 & 25 & 22 & 53 & 55 \\
\hline 5 & & 28 & 23 & 24 & 53 & 50 \\
\hline 6 & \multirow{4}{*}{ (3) } & 3 & 28 & 22 & 50 & 60 \\
\hline 7 & & 7 & 26 & 25 & 49 & 55 \\
\hline 8 & & 14 & 22 & 26 & 52 & 50 \\
\hline 9 & & 28 & 18 & 27 & 55 & 40 \\
\hline 10 & \multirow{4}{*}{ (4) } & 3 & 27 & 23 & 50 & 55 \\
\hline 11 & & 7 & 25 & 26 & 49 & 50 \\
\hline 12 & & 14 & 21 & 28 & 51 & 45 \\
\hline 13 & & 28 & 17 & 28 & 55 & 40 \\
\hline
\end{tabular}

Legend:

(1) Sandy clay $(\mathrm{saCl})$

(2) Sandy clay $+1,5 \%$ lime-based binder

(3) Sandy clay $+2,0 \%$ lime-based binder

(4) Sandy clay $+2,5 \%$ lime-based binder

$\mathrm{T}_{\text {curing }}$ - curing time (days)

In order to further determine the mechanical characteristics, cylindrical samples have been prepared from the previously prepared admixtures by compaction at $95 \%$ compaction degree. Samples were cured for 3, 7, 14 and 28 days and then the compression strength has been determined. Results are presented table 2 and also in figure 4 .

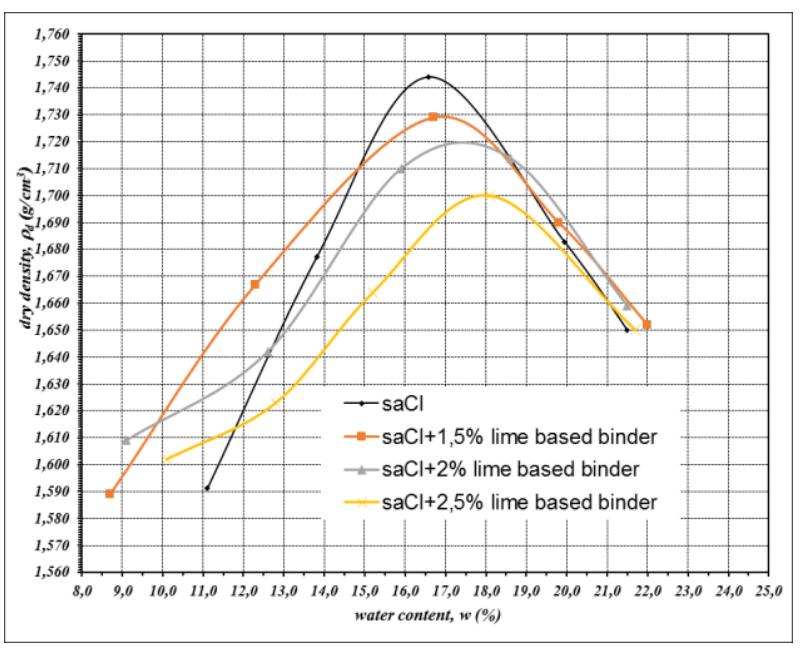

Fig. 2. Compaction curves for normal Proctor test $(\mathrm{L}=0.6$ $\left.\mathrm{MJ} / \mathrm{m}^{3}\right)$.

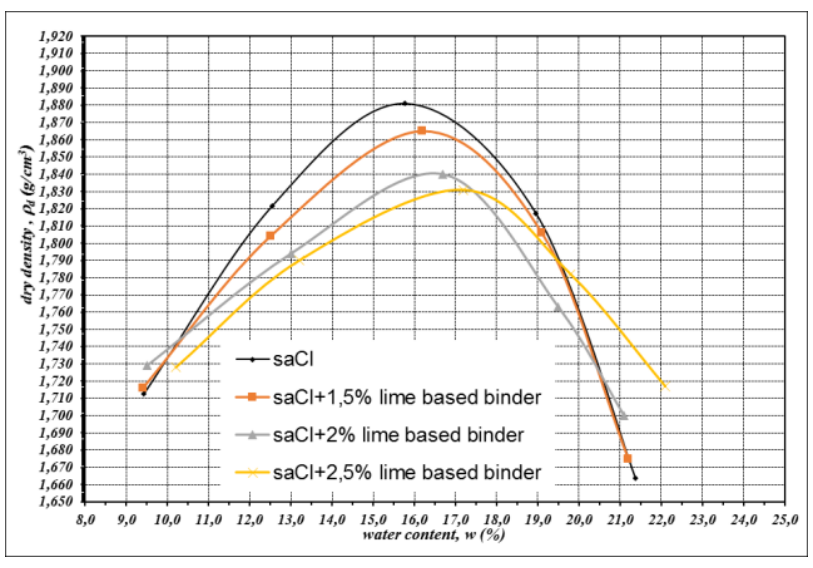

Fig. 3. Compaction curves for modified Proctor test $(\mathrm{L}=2.7$ $\left.\mathrm{MJ} / \mathrm{m}^{3}\right)$.

Table 2. Compression strength of treated soils.

\begin{tabular}{|c|c|c|c|c|c|c|c|}
\hline \multicolumn{2}{|c|}{$\begin{array}{c}\text { Lime-based } \\
\text { binder } \\
\text { addition }\end{array}$} & \multicolumn{2}{|c|}{$\begin{array}{c}\text { Compaction } \\
\text { characteristics } \\
\text { normal } \\
\text { Proctor }(\mathrm{PN}) \\
\text { modified } \\
\text { Proctor }(P M) \\
\end{array}$} & \multicolumn{4}{|c|}{$\begin{array}{c}\text { Compression strength } \\
\left(\mathrm{N} / \mathrm{mm}^{2}\right) \text { for curing time } \\
\text { (days) } \\
\text { normal Proctor }(\mathrm{PN}) \\
\text { modified Proctor }(\mathrm{PM})\end{array}$} \\
\hline$(\%)$ & $\begin{array}{l}(\mathrm{kg} / \\
\left.\mathrm{m}^{3}\right)\end{array}$ & $\begin{array}{c}\rho_{\mathrm{dmax}} \\
(\mathrm{g} / \\
\left.\mathrm{cm}^{3}\right)\end{array}$ & $\begin{array}{l}\mathrm{W}_{\mathrm{oc}} \\
(\%)\end{array}$ & 3 & 7 & 14 & 28 \\
\hline \multirow{2}{*}{1.5} & 26 & 1.73 & 17 & 0.63 & 0.80 & 1.02 & 1.17 \\
\hline & 28 & 1.865 & 16.2 & 0.76 & 0.94 & 1.15 & 1.37 \\
\hline \multirow[t]{2}{*}{2.0} & 34 & 1.72 & 17.5 & 0.70 & 0.87 & 1.09 & 1.26 \\
\hline & 36 & 1.84 & 16.8 & 0.85 & 1.02 & 1.28 & 1.49 \\
\hline \multirow[t]{2}{*}{2.5} & 41 & 1.7 & 18 & 0.79 & 0.99 & 1.26 & 1.41 \\
\hline & 45 & 1.83 & 17.2 & 0.92 & 1.18 & 1.48 & 1.66 \\
\hline
\end{tabular}

Legend: $\rho_{\mathrm{dmax}}-$ maximum dry density, woc - optimum water content 


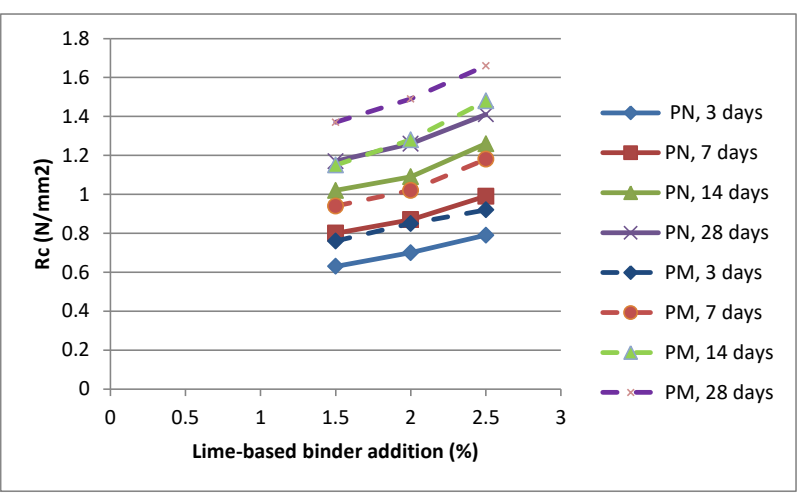

Fig. 4. Compression strength for various addition of lime-based binder $(1.5 \%, 2 \%, 2.5 \%)$ for samples prepared by compaction at normal (PN) or modified Proctor (PM) energy.

As expected, the compression strength depends on lime addition and curing time, but also on the compaction energy. Higher compaction energy (modified Proctor) led to higher compression strength values by an average of $20 \%$ compared to the lower energy (normal Proctor). Strengths are increasing with the addition percentage and, of course, with the curing time. It is interested to note that samples prepared by modified Proctor compaction (2.7 $\mathrm{MJ} / \mathrm{m}^{3}$ ) after only 3 days of curing have a strength equal to the minimum value accepted for using the stabilised soil as base layer, according to STAS 10473/2-86 (0.8 $\mathrm{N} / \mathrm{mm}^{2}$ ). This leads to reduction of curing time before service or before laying the next layer. On longer term, after 7 days of curing it can be seen that strength of samples compacted at higher energy $\left(2.7 \mathrm{MJ} / \mathrm{m}^{3}\right)$ have strengths higher than the minimum required ones according to STAS 12253-84.

The results of oedometer compressibility tests are presented in Table 3 and figure 5.

Table 3. Compressibility characteristics of treated soils samples prepared at $95 \%$ of optimum (normal or modified Proctor).

\begin{tabular}{|c|c|c|c|c|}
\hline \multirow{2}{*}{$\begin{array}{c}\begin{array}{c}\text { Lime- } \\
\text { based } \\
\text { binder } \\
\text { addition }\end{array} \\
(\%)\end{array}$} & \multirow[t]{2}{*}{$\begin{array}{l}\text { Curing } \\
\text { time } \\
\text { (days) }\end{array}$} & \multicolumn{2}{|c|}{$\begin{array}{c}\text { Density } \\
\text { normal Proctor } \\
\text { (PN) } \\
\text { modified Proctor } \\
\text { (PM) }\end{array}$} & \multirow{2}{*}{$\begin{array}{c}\text { Oedometric } \\
\text { modulus } \\
\mathrm{E}_{\text {oed }}\left(\mathrm{M}_{200-}\right. \\
300)(\mathrm{kPa}) \\
\text { normal } \\
\text { Proctor } \\
\text { (PN) } \\
\text { modified } \\
\text { Proctor } \\
\text { (PM) }\end{array}$} \\
\hline & & $\begin{array}{c}\text { Dry } \\
\text { density } \\
\left(\mathrm{g} / \mathrm{cm}^{3}\right)\end{array}$ & $\begin{array}{c}\text { Water } \\
\text { content } \\
(\%)\end{array}$ & \\
\hline \multirow[t]{4}{*}{1.5} & \multirow[t]{2}{*}{7} & 1.641 & 15.8 & 11111 \\
\hline & & 1.78 & 14.5 & 12500 \\
\hline & \multirow[t]{2}{*}{28} & 1.645 & 14.2 & 15385 \\
\hline & & 1.77 & 13.7 & 15385 \\
\hline \multirow[t]{4}{*}{2.0} & \multirow[t]{2}{*}{7} & 1.637 & 15.3 & 11765 \\
\hline & & 1.752 & 14.1 & 14286 \\
\hline & \multirow[t]{2}{*}{28} & 1.635 & 13.8 & 16667 \\
\hline & & 1.75 & 13.4 & 18182 \\
\hline \multirow[t]{4}{*}{2.5} & \multirow[t]{2}{*}{7} & 1.62 & 14.9 & 14286 \\
\hline & & 1.732 & 13.9 & 15385 \\
\hline & \multirow[t]{2}{*}{28} & 1.615 & 13.4 & 22222 \\
\hline & & 1.735 & 13 & 25000 \\
\hline
\end{tabular}

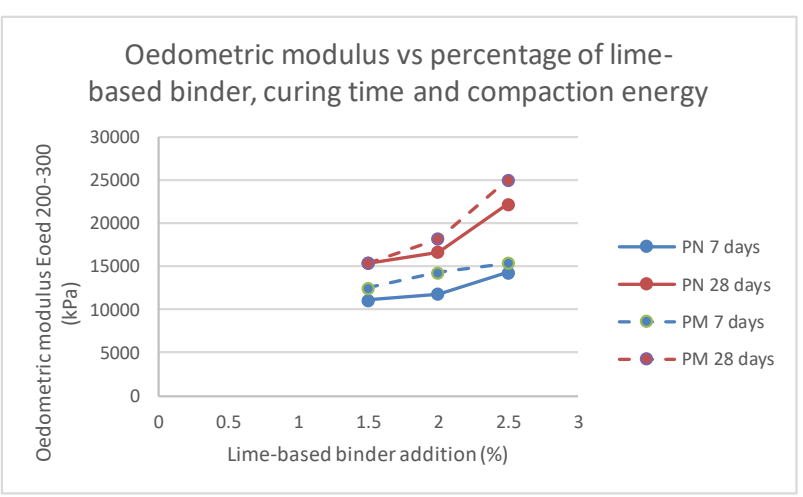

Fig. 5. Oedometric modulus ( $\left.\mathrm{E}_{\text {oed }} 200-300\right)$ for various addition of lime-based binder $(1.5 \%, 2 \%, 2.5 \%)$ for samples prepared by compaction at normal (PN) or modified Proctor (PM) energy.

As for the compression strength, the oedometric modulus has increased for modified Proctor energy (2.7 $\mathrm{MJ} / \mathrm{m}^{3}$ ) compared to normal Proctor energy and also with the percentage of lime-based binder. The use of modified Proctor compaction energy led to an increase of up to $20 \%$ of the oedometric modulus compared to normal Proctor energy.

For this work were performed also Lukas plate tests on 2 experimental plots which were using the same soil (sandy clay) mixed with 2\% lime-based binder. The difference between the two experimental plots consists in the compaction characteristics: plot 1 was executed at $98 \%$ of the normal Proctor optimum, while plot 2 at $98 \%$ of the modified Proctor optimum. Tests have been performed in 2 locations $(\mathrm{km} 0+050$ and $\mathrm{km} 0+100)$ at 1 day, 7 days and 14 days after mixing, Tests for 28 days after mixing are not yet carried out.

Results are presented in table 4 and figure 6 and are showing that also on field the deformation moduli $\mathrm{E}_{\mathrm{v} 1}$ and $E_{\mathrm{v} 2}$ are higher for high compaction energy by $4-28 \%$ compared to normal Proctor energy.

Table 4. Lukas plate tests on experimental plots $1(98 \%$ Proctor normal PN) and 2 (98\% Proctor modified PM) for 2\% lime-based binder addition.

\begin{tabular}{|c|c|c|c|c|c|c|c|}
\hline \multirow{3}{*}{$\frac{\overrightarrow{0}}{2} \stackrel{\dot{g}}{9}$} & \multirow{3}{*}{$\begin{array}{l}\text { Test } \\
\text { no. } \\
\text { km }\end{array}$} & \multicolumn{6}{|c|}{$E_{\mathrm{v} 1}$ and $E_{\mathrm{v} 2}(\mathrm{MPa})$ for curing time } \\
\hline & & \multicolumn{2}{|c|}{1 day } & \multicolumn{2}{|c|}{7 days } & \multicolumn{2}{|c|}{14 days } \\
\hline & & $E_{\mathrm{v} 1}$ & $E_{\mathrm{v} 2}$ & $E_{\mathrm{v} 1}$ & $E_{\mathrm{v} 2}$ & $E_{\mathrm{v} 1}$ & $E_{\mathrm{v} 2}$ \\
\hline \multirow[t]{2}{*}{$\begin{array}{c}1 \\
\text { PN }\end{array}$} & $\begin{array}{c}10+ \\
050\end{array}$ & 42.6 & 67.4 & 57.7 & 93.6 & 81.2 & 121.2 \\
\hline & $\begin{array}{c}20+1 \\
00\end{array}$ & 35 & 68.8 & 51.9 & 99.6 & 76.4 & 112 \\
\hline \multirow[t]{2}{*}{$\begin{array}{c}2 \\
\mathrm{PM}\end{array}$} & $\begin{array}{c}10+0 \\
50\end{array}$ & 44.8 & 86.3 & 73.6 & 119.5 & 85.1 & 127.1 \\
\hline & $\begin{array}{c}20+1 \\
00\end{array}$ & 41.9 & 88.6 & 61.4 & 113.5 & 81.2 & 130.1 \\
\hline
\end{tabular}

\section{Conclusions}

Improving low quality soils by mixing with lime-based binder can be an effective solution for using local soils in earthworks, mainly for road embankments. In order to obtain good physical and mechanical characteristics of the 
improved soils the key factors are the mixing process, but also the compaction energy and curing time.

Evolution Ev1, Ev2 vs curing time and compaction energy

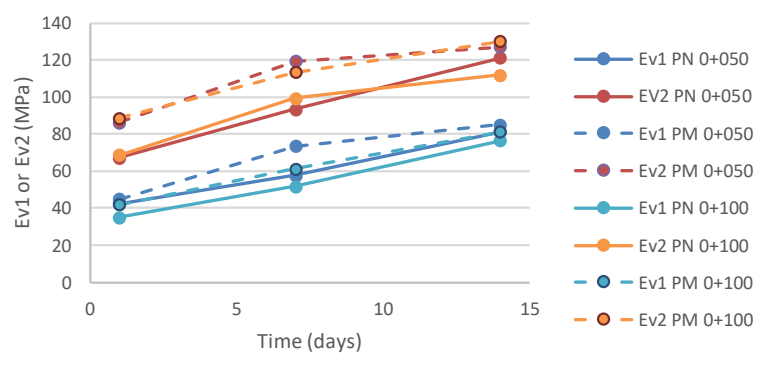

Fig. 6. Lukas plate test results for $2 \%$ addition of lime-based binder for various curing times and different compaction energies (normal proctor - PN and modified Proctor - PM).

Among the parameters of influence, the curing conditions (temperature, water content etc.) are also important.

The paper studied the influence of the compaction energy on the characteristics of improved soils by means of laboratory and field tests for a sandy clay mixed with lime-based binder in three proportions $(1.5 \%, 2 \%, 2.5 \%)$. Also, various curing time have been considered.

The results showed clearly that a high compaction energy, as for example the one corresponding to modified Proctor test, leads to higher mechanical characteristics (unconfined compression strength, deformation moduli) than lower energies. This is an important feature to be applied on site, considering that in case of high compaction energy the required mechanical characteristics can be obtained after shorter curing times.

Obtained results are in line with other researchers findings [4], [7], [8].

Authors would like to acknowledge CARMEUSE Holding for providing the binder and for the technical and financial support.

\section{References}

1. Centre de recherches routiers Belgia CRR, Guide technique Code de bonne pratique pour le traitement des sols a la chaux et/ ou aux liants hydrauliques (Technical guidelines, Belgium, 2004)

2. Le Laboratoire Central des Ponts et Chaussées, Le Service d'Études Techniques des Routes et Autoroutes, Guide technique Traitement des sols à la chaux et/ou aux liants hydrauliques. Application à la realisation des remblais et des couches de forme (Technical guidelines, France, 2000)

3. Beetham, P., Dijkstra, T., Dixon, N., Nucleation centres in lime stabilised soils, Proceedings of ISSMGE - TC 211 International Symposium on Ground Improvement IS-GI Brussels 31 May \& 1 June 2012, vol. II pp. 269 - 279 (2012)
4. Lutenegger, A.J., Immediate modification of clays with quicklime: alteration of grainsize distribution, Proceedings of ISSMGE - TC 211 International Symposium on Ground Improvement IS-GI Brussels 31 May \& 1 June 2012, vol. II, pp. 251-260 (2012)

5. ASRO, STAS 12253-84 (Road works. Base layers. General technical quality specifications - in Romanian)

6. ASRO, STAS 10473/1-87 (Layers from natural aggregates or cement-stabilized soils. General technical quality specifications - in Romanian)

7. Abbasi, N., Mahdieh, M., Davousi, M.H., Improvement of Geotechnical Properties of Silty sand Soils Using Natural Pozzolan and Lime, Proceedings of ISSMGE - TC 211 International Symposium on Ground Improvement IS-GI Brussels 31 May \& 1 June 2012, vol. II, pp. 251-260 (2012)

8. Saussaye, L., Boutouil, M. et al, Soils treatment with hydraulic binders: physicochemical and geotechnical investigations of a chemical disturbance, Proceedings of ISSMGE - TC 211 International Symposium on Ground Improvement IS-GI Brussels 31 May \& 1 June 2012, vol. II, pp. $479-488$ (2012) 